\title{
Correction to: Silencing of a BAHD acyltransferase in sugarcane increases biomass digestibility
}

\author{
Wagner Rodrigo de Souza 1,2 , Thályta Fraga Pacheco ${ }^{1}$, Karoline Estefani Duarte ${ }^{1}$, Bruno Leite Sampaio , \\ Patrícia Abrão de Oliveira Molinari' ${ }^{1}$, Polyana Kelly Martins' ${ }^{1}$, Thaís Ribeiro Santiago', \\ Eduardo Fernandes Formighieri ${ }^{1}$, Felipe Vinecky ${ }^{1}$, Ana Paula Ribeiro ${ }^{1}$, Bárbara Andrade Dias Brito da Cunha ${ }^{1}$, \\ Adilson Kenji Kobayashi ${ }^{1}$, Rowan Andrew Craig Mitchell ${ }^{3}$, Dasciana de Sousa Rodrigues Gambetta ${ }^{1}$ \\ and Hugo Bruno Correa Molinari ${ }^{1 *}$ (i)
}

\section{Correction to: Biotechnol Biofuels (2019) 12:111 https://doi.org/10.1186/s13068-019-1450-7}

After the publication of the article [1], it was brought to our attention that the GenBank Accession number for the EF1 is missing in Methods section. Please find the accession number in the erratum below.

\section{Expression analysis of SacBAHD genes in sugarcane leaves}

Top leaves (a pool of four fully expanded leaves) of 3- and 8-month-old SP80-3280 sugarcane variety were collected for expression analysis of the identified SacBAHD genes (SacBAHD01, 03, 05 and 09) from three different plants. Total RNA was isolated using TRIzol reagent (Invitrogen, Grand Island, NY) and treated with RNaseFree RQ1 DNase (Promega, San Luis Obispo, CA) according to the manufacturer's instructions. cDNA was synthesized from one $\mu \mathrm{g}$ of RNA using SuperScript ${ }^{\circledR}$ III kit (Invitrogen). The expression level was normalized against the sugarcane Glyceraldehyde 3-phosphate dehydrogenase (GAPDH) and Elongation factor 1-alpha (EF1) genes by qRT-PCR. The reactions were performed with SYBR Green Master Mix (Applied Biosystems) under the following conditions: $95^{\circ} \mathrm{C}$ for 3 min denaturation, 40 cycles at $95{ }^{\circ} \mathrm{C}$ for $10 \mathrm{~s}$, and $58{ }^{\circ} \mathrm{C}$ for $45 \mathrm{~s}$. Amplification specificity was verified by melt curve analysis from 55 to $95^{\circ} \mathrm{C}$.

\footnotetext{
*Correspondence: hugo.molinari@embrapa.br

${ }^{1}$ Genetics and Biotechnology Laboratory, Embrapa Agroenergy (CNPAE) Brasília, DF 70770-901, Brazil

Full list of author information is available at the end of the article
}

SacBAHD expression levels were calculated using the $2^{-\Delta \Delta \mathrm{Ct}}$ method [59]. The primers' sequences used for GAPDH (CA254672), EF1 (EF581011.1), and SacBAHDs (SacBAHD1: MK614571; SacBAHD3: MK614570; SacBAHD5: MK614573; SacBAHD9: MK614572) amplifications are listed in Additional file 6: Table S3.

\section{Author details \\ ${ }^{1}$ Genetics and Biotechnology Laboratory, Embrapa Agroenergy (CNPAE), Brasília, DF 70770-901, Brazil. ${ }^{2}$ Centre of Natural Sciences and Humanities, Fed- eral University of ABC, São Bernardo do Campo, SP 09606-045, Brazil. ${ }^{3}$ Plant Sciences, Rothamsted Research, Harpenden, Hertfordshire AL5 2JQ, UK. \\ The original article can be found online at https://doi.org/10.1186/s1306 8-019-1450-7.}

Received: 21 December 2018 Accepted: 25 April 2019

Published online: 08 June 2019

\section{Reference}

1. de Souza WR, Pacheco TF, Duarte KE, Sampaio BL, de Oliveira Molinari PA, Martins PK, Santiago TR, Formighieri EF, Vinecky F, Ribeiro AP, da Cunha BA, Kobayashi AK, Mitchell RAC, de Sousa Rodrigues Gambetta D, Molinari HBC. Silencing of a BAHD acyltransferase in sugarcane increases biomass digestibility. Biotechnol Biofuels. 2019;12:111. https://doi. org/10.1186/s13068-019-1450-7.

\section{Publisher's Note}

Springer Nature remains neutral with regard to jurisdictional claims in published maps and institutional affiliations. 